\title{
Effect of antioxidant supplements on testicular histo-morphology in adult male
} guinea pigs

(Cavia porcellus)

${ }^{* 1}$ Gaddafi, S., ${ }^{1}$ Garba, M. G., ${ }^{2}$ Abdulrashid, M., ${ }^{2}$ Zahraddeen, D., ${ }^{2}$ Daudou, O. M. and ${ }^{3}$ Iyeghe-Erakpotobor, G. T.

${ }^{I}$ Department of Animal Science, Federal University Dutsin-ma, Nigeria,

${ }^{2}$ Department of Animal Science, Ahmadu Bello University Zaria, Nigeria

${ }^{3}$ National Animal Production Research Institute, Zaria, Nigeria

*corresponding author: sanigaddafi4@gmail.com; +234(7)067212353

Abstract

The study was carried out to evaluate the biopotency of antioxidant supplements on physiological, testicular and oxidative biomarkers in adult male guinea pigs (Cavia porcellus). A total of 60 adult male guinea pigs of three months of age with an average body weight of $500 \pm 20 \mathrm{~g}$ were randomly allocated into three dietary treatment groups of vitamin $C$, vitamin E and selenium and each comprised four varying levels with five animals per group in a completely randomized design (CRD). Feed and water were provided ad-libitum. The testicular morphology showed a significant $(P<0.05)$ difference in weight of right testis, weight of left testis, paired testis weight, right testis width, testis volume, testis density, right testis length and left testis length of guinea pig supplemented varying dosage of vitamin $C, E$ and Selenium. microphotograph indicated considerable changes in seminiferous tubules density, size, and other morphological characteristics, also intertubular space, basement membrane, leydigs cells and spermatogonia of the guinea pigs supplemented varying dosage of vitamin $C, E$ and Selenium revealed considerable changes. The supplementation of adult male guinea pigs diets with $200 \mathrm{mg}$ vitamin $C$ had the highest values of testicular morphometric followed by $15 \mathrm{mg}$ vitamin $\mathrm{E}$ group and $0.3 \mathrm{mg}$ of selenium. Similarly, considerable histo-architectural changes in seminiferous tubules and interstitial cells size and shape occurred in guinea pigs supplemented 200, 15 and $0.3 \mathrm{mg}$ per $\mathrm{kg}$ diet vitamin $C, E$ and selenium respectively. Therefore, supplementation of vitamin $C, E$ and Selenium has a profound effect on testicular histo-morphology of adult male guinea pigs.

Keywords: oxidative biomarkers, spermatogonia, adult male guinea pigs, vitamin $C, E$ and Selenium

\section{L'Effet des suppléments antioxydants sur l'histomorphologie testiculaire chez les} cobayes mâles adultes (Caviaporcellus)

${ }^{* 1}$ Gaddafi, S., ${ }^{1}$ Garba, M. G., ${ }^{2}$ Abdulrashid, M., ${ }^{2}$ Zahraddeen, D., ${ }^{2}$ Daudou, O. M. et

${ }^{3}$ Iyeghe-Erakpotobor, G. T.

${ }^{I}$ Department of Animal Science, Federal University Dutsin-ma, Nigeria,

${ }^{2}$ Department of Animal Science, Ahmadu Bello University Zaria, Nigeria

${ }^{3}$ National Animal Production Research Institute, Zaria, Nigeria

*corresponding author: sanigaddafi4@gmail.com; +234(7)067212353

Résumé

L'étude a été réalisée pour évaluer la biopotence des suppléments antioxydants sur les biomarqueurs physiologiques, testiculaires et oxydatifs chez les cobayes mâles adultes (Caviaporcellus). Un total de 60 cobayes mâles adultes de trois mois avec un poids corporel moyen de $500 \pm 20 \mathrm{~g}$ ont été répartis au hasard dans trois groupes de traitement diététique de 
vitamine $C$, vitamine E et sélénium et chacun comprenait quatre niveaux variables avec cinq animaux par groupe en une conception complètement aléatoire. L'alimentation et l'eau étaient fournies ad libitum. La morphologie testiculaire a montré une différence significative $(P<0,05)$ du poids du testicule droit, du poids du testicule gauche, du poids du testicule apparié, de la largeur du testicule droit, du volume du testicule, de la densité du testicule, de la longueur du testicule droit et de la longueur du testicule gauche du cobaye supplémenté en doses variables de vitamine $C$, E et sélénium. La microphotographie a indiqué des changements considérables dans la densité, la taille et d'autres caractéristiques morphologiques des tubules séminifères, ainsi que l'espace intertubulaire, la membrane basale, les cellules de 'leydigs' et la spermatogonie des cobayes complétés par des doses variables de vitamine $C, E$ et de sélénium ont révélé des changements considérables. La supplémentation des régimes alimentaires de cobayes mâles adultes avec $200 \mathrm{mg}$ de vitamine Cavait les valeurs les plus élevées de morphométrie testiculaire suivie par $15 \mathrm{mg}$ de groupe de vitamine $E$ et $0,3 \mathrm{mg}$ de sélénium. De même, des changements histoarchitecturaux considérables de la taille et de la forme des tubules séminifères et des cellules interstitielles se sont produits chez les cobayes ayant reçu respectivement 200, 15 et 0,3 mg par $\mathrm{kg}$ de vitamine $C$, E et de sélénium. Par conséquent, la supplémentation en vitamine $C, E$ et en sélénium a un effet profond sur l'histomorphologie testiculaire des cobayes mâles adultes.

Mots clés : antioxydants sur les biomarqueurs, cobayes mâles adultes, Vitamine $\mathrm{C}$, E, et de sélénium,

\section{Introduction}

Guinea pigs are docile, stocky, and tailless rodent that weigh between $700 \mathrm{~g}$ to $1500 \mathrm{~g}$, with males being larger than females. The guinea pig is well recognized worldwide for its contributions to science as an experimental or laboratory animal. It is a particularly valuable animal for nutritional research because of its unusually high requirement for certain vitamins and amino acids. They are also used extensively in research laboratories to study medicine, physiology and hereditary (Lammers et al., 2009). The testes are primary organs of reproduction in the male because they produce male gametes (Spermatozoa) and male sex hormones (androgen). The basis for a sound knowledge of the male reproductive physiology in any species lies in the detailed morpho-functional study of its reproductive organs (Adebayo et al., 2015). Many studies have been carried out on testes morphometry of different animals like the boar (Lunstra et al., 2003), mules (Neves et al., 2002), cats (Franca and
Godinho, 2003), domestic chicken (Okpe et al., 2010) etc. However, few data are available on testis morphometry and histology of guinea pigs. Vitamin $\mathrm{C}$ is a water soluble antioxidant. In contrast to many mammals, humans and guinea pigs are unable to synthesize vitamin $\mathrm{C}$ due to the lack of the enzyme L-gulono-gammalactone oxidase (Jesse et al., 2007). Vitamin $\mathrm{C}$ is found in citrus, soft fruits and leafy green vegetables. Kidney and liver are good animal derived sources of vitamin $\mathrm{C}$ (Stangeland et al., 2008). Vitamin C can be administered orally or intravenously (Padayatty et al., 2008). It is well absorbed efficiently in the small intestine via a saturable active transport mechanism. Vitamin C is widely distributed in all tissues of the body, with higher levels found in the adrenal glands, pituitary and retina. Kidney and muscle tissues have lower level of vitamin C (Wandzilak et al., 2013). Selenium is an essential micronutrient required for normal growth and maintenance in livestock. Recently, 


\section{Gaddafi, Garba, Abdulrashid, Zahraddeen, Daudou and Iyeghe-Erakpotobor}

selenium (Se) has been recognized as an essential dietary nutrient. Dietary selenium is an essential trace element for animals and humans with a variety of biological function (Surai and Sparks, 2006). These compounds are necessary for growth, fertility, immune system, hormone metabolism, cell growth and antioxidant defense systems in animals and humans (Pappas and Zoidis, 2012). Since vitamin E acts as a tissue antioxidant and aids in quenching free-radicals produced in the body, any infection or other stress factors may exacerbate depletion of the limited vitamin $\mathrm{E}$ stores from various tissues. The protective effects of vitamin $\mathrm{E}$ on animal health may be involved with its role in reduction of glucocorticoids, which are known to be immunosuppressive. Vitamin E also most likely has an immune enhancing effect by virtue of altering arachidonic acid metabolism and subsequent synthesis of prostaglandin, thromboxanes and leukotrienes. Under stress conditions, increased levels of these compounds by endogenous synthesis or exogenous entry may adversely affect immune cell function (Hadden, 1987). The present study improved on the available information on testicular morphometry and histology of guinea pigs fed diet supplemented varying levels of vitamin $C$, vitamin $\mathrm{E}$ and selenium.

\section{Materials and methods Experimental site}

The experiment was conducted at the teaching and research farm of the Department of Animal Science Ahmadu Bello University, Samaru, Zaria. The farm is located between latitude $11^{\circ} 9^{\prime} 45^{\prime \prime} \mathrm{N}$ and $7^{\circ} 38^{\prime} 8^{\prime \prime} \mathrm{E}$ longitude at an altitude of $610 \mathrm{~m}$ above sea level (Ovimaps, 2015). Zaria town is part of Northern Guinea Savannah between latitudes $11^{\circ}$ and $12^{\circ} \mathrm{N}$ and between longitude $7^{\circ}$ and $8^{\prime} \mathrm{E}$ at an altitude of $640 \mathrm{~m}$ above sea level. The climate of the area is sub-humid; rainfall is well distributed during the rainy season, with a mean annual rainfall of $1100 \mathrm{~mm}$. The rainy season starts from late April or early midOctober and about $70 \%$ of the rain occurs during the months of July and August, followed by the harmattan period of cool and dry weather which usually lasts from October to February. This is then followed by hot-dry weather from March to April, known as pre-rain period. The average ambient temperature and relative humidity during the wet season are $24.7^{\circ} \mathrm{C}$ and $72 \%$ respectively. This is followed by the hot weather when temperatures fluctuate during day from 13 to $36^{\circ} \mathrm{C}$ with a mean relative humidity of 20-37\% (IAR 2016)

\section{Experimental animals and design}

A total of 60 adult male guinea pigs of three months of age with an average body weight of $500 \pm 20 \mathrm{~g}$ were randomly allocated into three dietary treatment groups of vitamin C, $\mathrm{E}$ and selenium and each comprised four varying levels with five animals per group in a completely randomized design (CRD). Feed and water were provided ad-libitum.

\section{Experimental diet and management}

The diet was formulated to meet the dietary recommendation for guinea pig under tropical condition (NRC, 1995). Twelve different diets were formulated comprising four levels of vitamin $C(0,100,200$, and $300 \mathrm{mg} / \mathrm{kg}$ of diet $)$, vitamin $\mathrm{E}(0,15,30$ and $45 \mathrm{mg} / \mathrm{kg}$ ) and $0,0.1,0.2$, and $0.3 \mathrm{mg} / \mathrm{kg}$ ) 


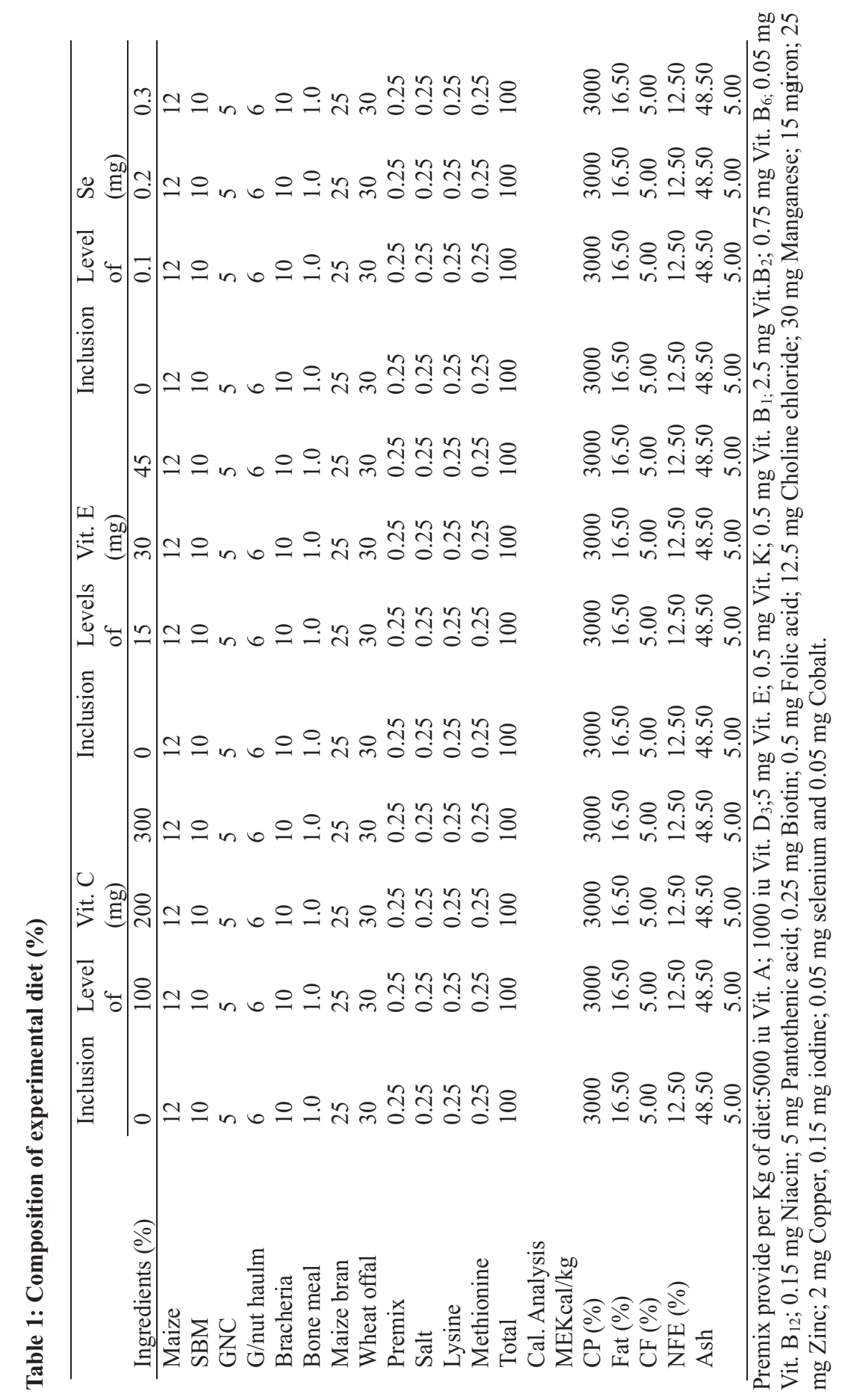


Gaddafi, Garba, Abdulrashid, Zahraddeen, Daudou and Iyeghe-Erakpotobor

Table 2: Proximate composition of experimental diet

\begin{tabular}{ll}
\hline Composition & $\%$ \\
\hline Metabolizable energy $(\mathrm{kcal} / \mathrm{kg})$ & 2734.46 \\
$\mathrm{CP}$ & 16.57 \\
$\mathrm{EE}$ & 4.97 \\
$\mathrm{CF}$ & 10.57 \\
$\mathrm{NFE}$ & 58.23 \\
Ash & 3.81 \\
\hline
\end{tabular}

\section{Testicular morphological parameters}

Three guinea pigs per treatment were slaughtered at the end of the experimental period. Immediately after slaughter the animals were taken to the meat laboratory and dissected to obtain the testes. The weight of the testes was obtained using a sensitive digital weighing scale. The volume of the testes was obtained using the Archimedes principle of water displacement. Relative testis weight was calculated as paired testes weight $\mathrm{x}$ 100/body weight. Testes density was calculated as testes weight/testes volume $(\mathrm{g} / \mathrm{ml})$. Testis length was measured using measuring tape (Eme and Egbunike, 2010).

\section{Histological study}

At the end of the study, four guinea pigs from each treatment were sacrificed and the testicles were carefully dissected and preserved in $10 \%$ formalin. The testicles were transported to the Department of Pathology, Ahmadu Bello Teaching University Teaching Hospital, Zaria for histological examination.

\section{Procedure for histological examination}

Fixation: testes were kept in $10 \%$ neutral buffered formalin solution for a period of 24 hours to achieved full penetration. $4 \mathrm{~mm}$ in thickness were cut from testis and placed into small perforated plastic containers (labeled cassettes) to segregate them from one another.

Dehydration: the labeled testicular specimens in cassettes were placed in a carrier basket and immersed into $10 \%$ neutral buffered formalin and put into LEICA ${ }^{\circledR}$ automatic tissue processing machine (Model Tp 1020, leica biosystem,
$\mathrm{GmbH}$, Germany). A series of increasing concentrations of ethanol was prepared in the automated machine and the specimens were immersed serially in ascending grades of ethanol for a specified duration of two hours each as follows: $70 \%$ ethanol, $90 \%$ ethanol, $10 \%$ ethanol, $100 \%$ ethanol, $100 \%$ ethanol and $100 \%$ ethanol. At the end of the session, residual water in the specimens would have been removed.

Clearing: testicular specimens was than cleared using toluene as intermediate solvent that is fully miscible with both ethanol and paraffin wax. Embedding and sectioning: the specimens were than infiltrated with molten paraffin wax at $60^{\circ} \mathrm{C}$ and allowed to coll to $20^{\circ} \mathrm{C}$ using leica ${ }^{\circledR}$ tissue embedding system machine. This has resulted in a block that would be clamped onto a rotary microtome for section cutting. Sections (3-4 microns) were cut and spread with the help of $20 \%$ alcohol, then were floated on water bath at $45^{\circ} \mathrm{C}$, and were taken on a slide and allowed to dry above melting point of wax on a hot plate at $65^{\circ} \mathrm{C}$. Staining was done in LEICA ${ }^{\circledR}$ automatic stainer to demonstrate general tissue section using haematoxylin and eosin staining technique. Samples were dewaxed for 5 minutes using xylene to remove paraffin wax. Absolute alcohol was used to remove xylene in two changes of 10 minutes each. Washing was done for 2 minutes at room temperature. This was followed by staining with meyer's haematoxylin for 15 minutes. Washing was done again in water for 2 minutes. This was followed by counterstaining with eosin, dehydrating with absolute alcohol and 
clearing with xylene. Mounting was done in the APES (amino-propyl-tri-ethoxysilane) coated slide mounter. The slide containing the tissue was finally covered with coverslips. The finished slide was labeled and examined under compound light microscope (LEICA ${ }^{\circ}$ ICC50 HD microscope).

\section{Statistical analysis}

Data were subjected to statistical analysis using the analysis of variance procedure of statistical analysis software (SAS, 2002). The treatment means were compared using the Duncan procedure of the same software.

\section{Result \\ Effect of Vitamin $C, E$ and Selenium on testicular morphology of adult male guinea pigs}

The testicular morphology results were presented in Table 3 The result revealed significant differences $(\mathrm{P}<0.05)$ in weight of the right testis, weight of the left testis, paired testis weight and testis density in guinea pigs fed diet supplemented with varying levels of vitamin C. Guinea pigs supplemented with $200 \mathrm{mg}$ vitamin $\mathrm{C} / \mathrm{kg}$ had the highest $(\mathrm{P}<0.05)$ values for weight of right testis $(4.80 \mathrm{~g})$, weight of left testis $(4.70 \mathrm{~g})$, paired testis weight $(9.30 \mathrm{~g})$ and testis density $(1.21 \mathrm{~g} / \mathrm{ml})$, while guinea pigs in $0 \mathrm{mg}$ vitamin $\mathrm{C} / \mathrm{kg}$ had the lowest value for these parameters. There were significant $(\mathrm{P}<0.05)$ differences in weight of left testis, right testis volume, left testis volume, testes volume, right testis length and left testis length in guinea pigs supplemented varying levels of vitamin E. Guinea pigs supplemented with $15 \mathrm{mg}$ vitamin $\mathrm{E} / \mathrm{kg}$ had the highest right testis volume $(3.67 \mathrm{~mL})$, left testis volume $(3.67 \mathrm{~mL})$, right testis length $(5.00 \mathrm{~mm})$ and left testis length $(5.00 \mathrm{~mm})$ values while guinea pigs in $0 \mathrm{mg}$ vitamin $\mathrm{E} / \mathrm{kg}$ had the lowest right testis volume, left testis volume, right testis length and left testis length of $1.87 \mathrm{ml}, 1.87 \mathrm{ml}, 2.50 \mathrm{~mm}$ and $3.07 \mathrm{~mm}$ respectively. The result also revealed no significant $(\mathrm{P}>0.05)$ differences in weight of right testis, paired testis weight, relative testes weight, testes density, right testis width and left testis width. There were significant difference in weight of right testis and weight of left testis in guinea pigs supplemented with varying levels of selenium with the highest values of $4.47 \mathrm{~g}$ and $4.50 \mathrm{~g}$ respectively recorded in those who had supplementation at $0.3 \mathrm{mg}$ selenium $/ \mathrm{kg}$. There were no significant $(\mathrm{P}>0.05)$ differences observed on other testicular morphological characteristics of guinea pigs supplemented varying levels of selenium.

\section{Effect of Vitamin $C, E$ and Selenium on} Testicular Histology

The photomicrograph observations of the testis in vitamin $\mathrm{C}$ control group $(0 \mathrm{mg} / \mathrm{kg}$ vitamin $C$ ) is presented in plate $A$, the seminiferous tubules (STs) are smaller and scanty. The spermatogenic cells and interstitial cells showed normal appearance. The guinea pigs supplemented with 100 (Plate B), 200 (Plate C) and $300 \mathrm{mg} / \mathrm{kg}$ vitamin $\mathrm{C}$ diet (Plate D) respectively, showed many histological changes. All the guinea pigs in those group developed increases in seminiferous tubules size and intertubular spaces. No testicular lesions or haemorrhage, widening of the central tubules lumen and germ cell necrosis observed in guinea pigs supplemented varying levels of vitamin $\mathrm{C}$.

The microscopic observations of the testis of guinea pigs fed diets supplemented with varying levels of vitamin $\mathrm{E}$ is presented from plate $E$ to $H$. The guinea pigs supplemented with $0 \mathrm{mg} / \mathrm{kg}$ vitamin $\mathrm{E}$ showed very smaller and dense seminiferous tubules, multiple vacuoles were seen within the tubules. However, a photomicrograph of a section of testis of guinea pigs supplemented 15, 30 and 45 $\mathrm{mg} / \mathrm{kg}$ vitamin E showed larger and dense 


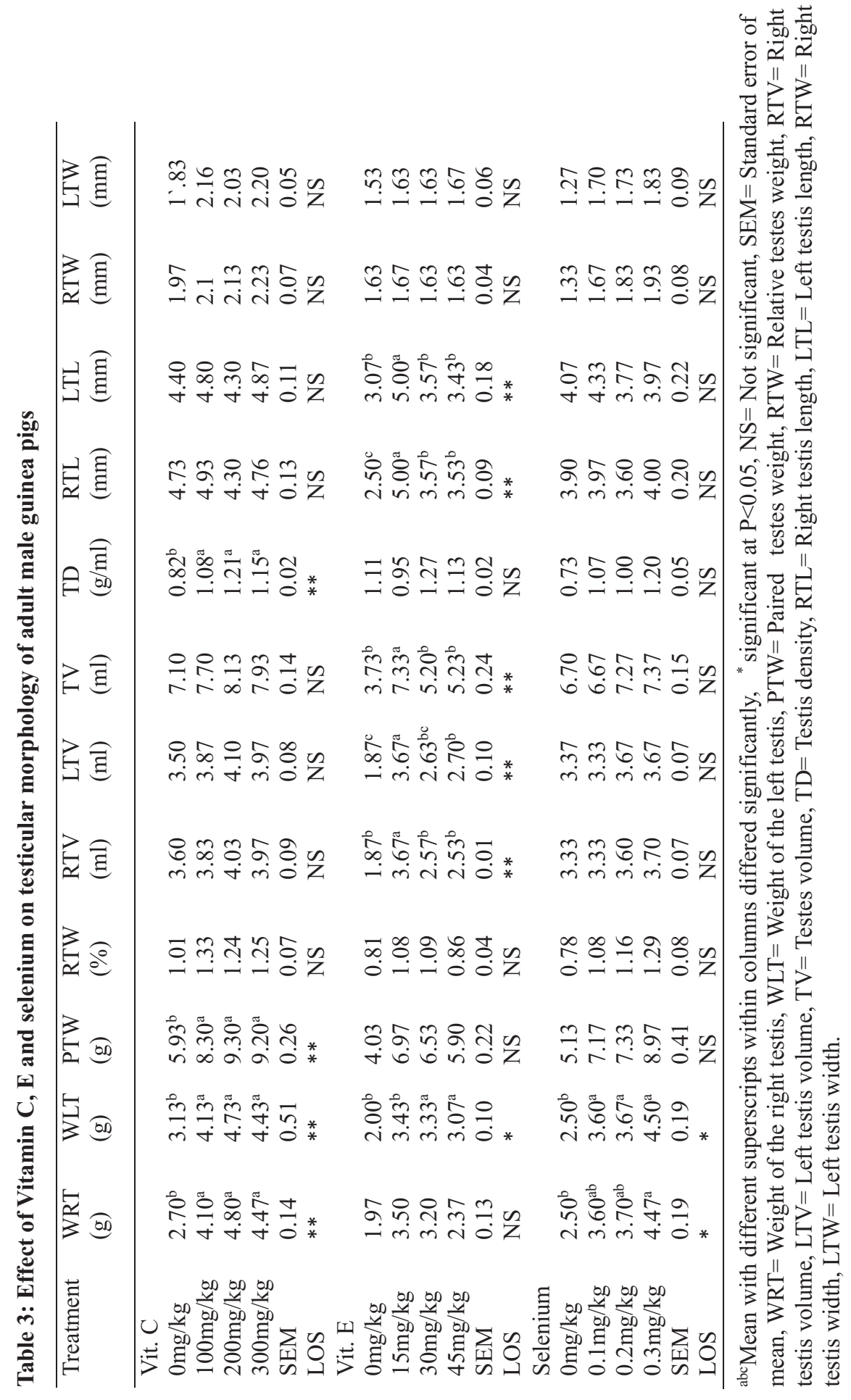




\section{Effect of antioxidant supplements on testicular histo-morphology in adult male guinea pigs (Cavia porcellus)}

seminiferous tubules with wider intertubular spaces. The tubules were separated from each other with widened interstitial space and had different shapes with irregular outlines in guinea pigs supplemented 30 and $45 \mathrm{mg} / \mathrm{kg}$ vitamin E. In 0 (plate I) and 0.1 (Plat J) $\mathrm{mg} / \mathrm{kg}$ selenium groups, the histological features were almost similar, testicular sections showed STs with near normal orderly

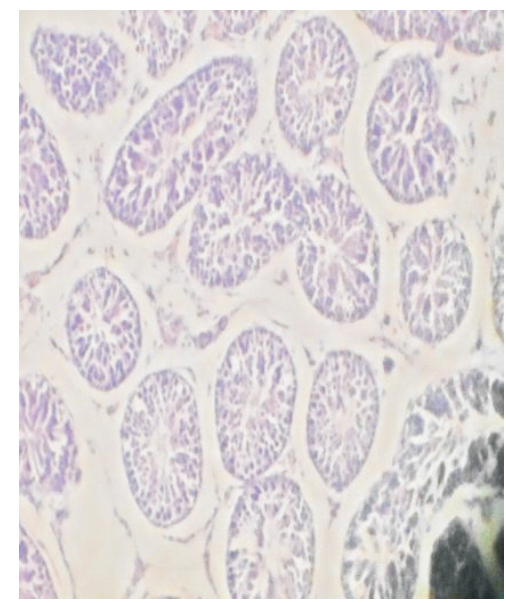

Plate A Photomicrograph of testicular tissue of Guinea pig supplemented with $0 \mathrm{mg}$ Vit. C. The seminiferous tubules were smaller and scanty. (Haematoxylin and Eosine $\mathrm{x} 400$ magnification)

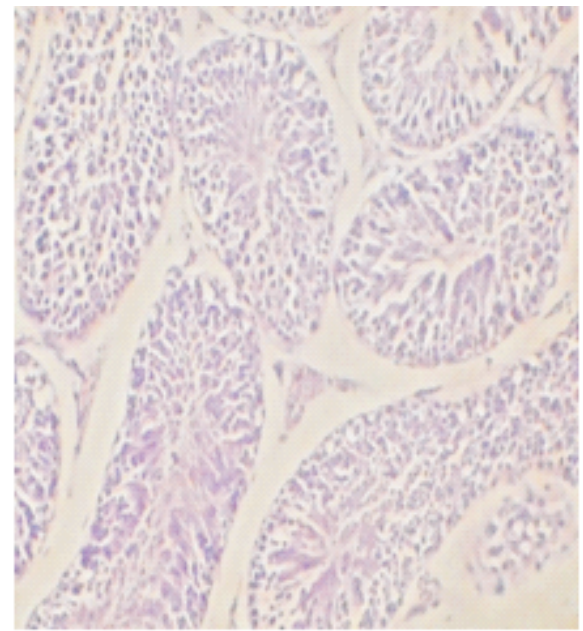

Plate C photomicrograph of testicular tissue of Guinea pig supplemented with $200 \mathrm{mg}$ Vit. C. There were increased intertubular spaces. (Haematoxylin and Eosine $\times 400$ magnification) arranged pattern up to mature spermatids. There were adequate sertoli cell populations. The microphotograph examination of the testicular tissue of guinea pigs supplemented $0.2 \mathrm{mg} / \mathrm{kg}$ selenium (Plate $\mathrm{K}$ ) revealed that the true architectural structure of STs are generalized dis-organizational and scanty with wider intertubular spaces while plate $\mathrm{L}$ $(0.3 \mathrm{mg} / \mathrm{kg}$ selenium $)$ showed dense and clustered seminiferous tubules.

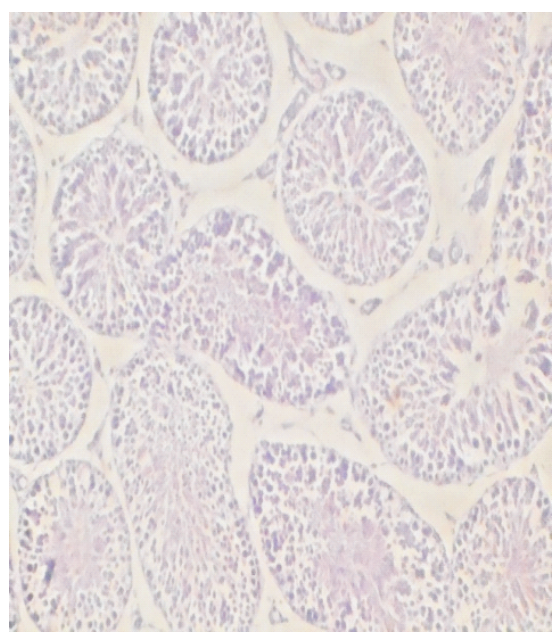

Plate B Photomicrograph of testicular tissue of Guinea pig supplemented with $100 \mathrm{mg}$ Vit. C Seminiferous tubules increased in size. (Haematoxylin and Eosine x400 magnification).

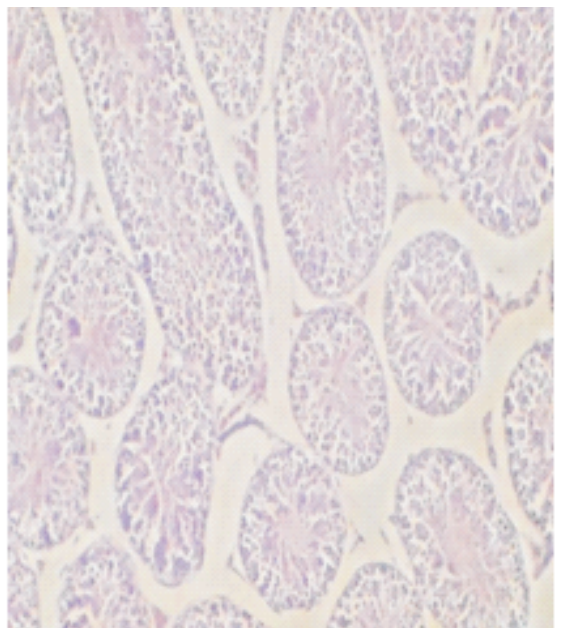

Plate D photomicrograph of testicular tissue of Guinea pig supplemented $300 \mathrm{mg}$ Vit. C. Enlongation occured in some seminiferous tubules. (Haematoxylin and Eosine staining $x 400$ 


\section{Gaddafi, Garba, Abdulrashid, Zahraddeen, Daudou and Iyeghe-Erakpotobor}

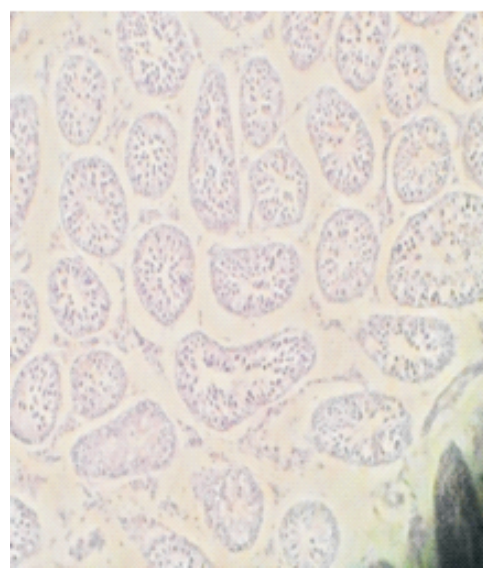

Plate E Photomicrograph of testicular tissue of Guinea pig supplemented with $0 \mathrm{mg}$ Vit. E. The seminiferous tubules are smaller and dense. (Haematoxylin and Eosine staining x400 magnification)

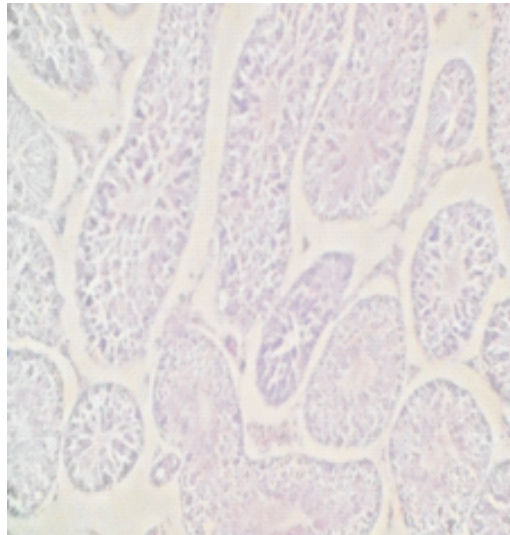

Plate G Photomicrograph of testicular tissue of Guinea pig supplemented with $30 \mathrm{mg}$ Vit. E. Enlongation of seminiferous tubules. (Haematoxylin and Eosine staining x400 magnification).

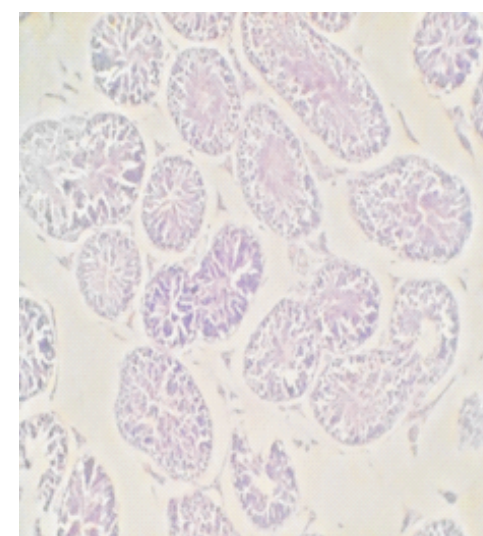

Plate I Photomicrograph of testicular tissue of Guinea pig supplemented with $0 \mathrm{mg}$ Se. Scanty and shrunken seminiferous tubules (Haematoxylin and Eosine staining $\mathrm{x} 400$ magnification)

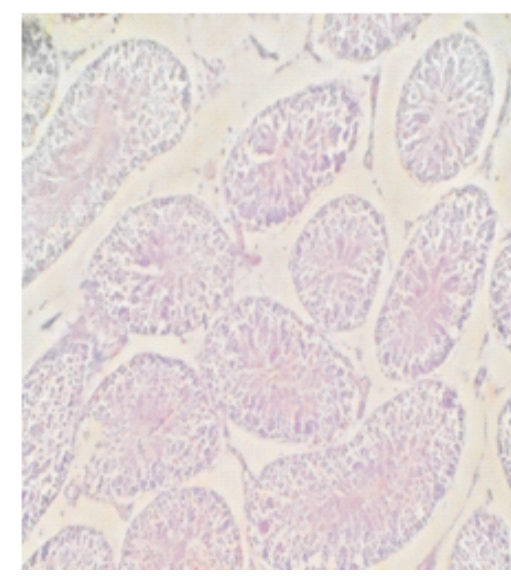

Plate F Photomicrograph of testicular tissue of Guinea pig supplemented $15 \mathrm{mg}$ Vit. E. The semineferous tubules become larger with wider intertubular spaces. (Haematoxylin and Eosine staining x400 magnification)

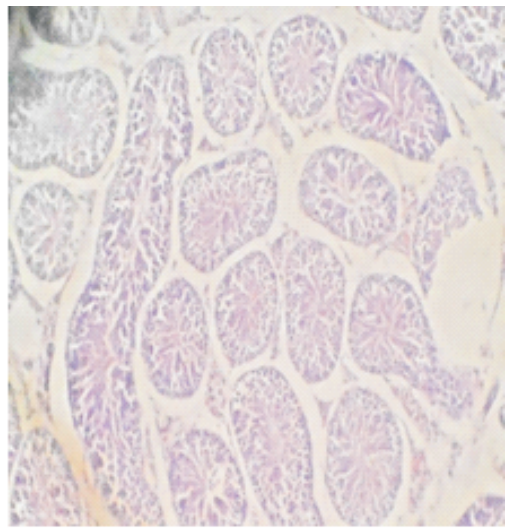

Plate H Photomicrograph of testicular tissue of Guinea pig supplemented with $45 \mathrm{mg}$ Vit. E. Very dense seminiferous tubules (Haematoxylin and Eosine Staining x400 magnification).

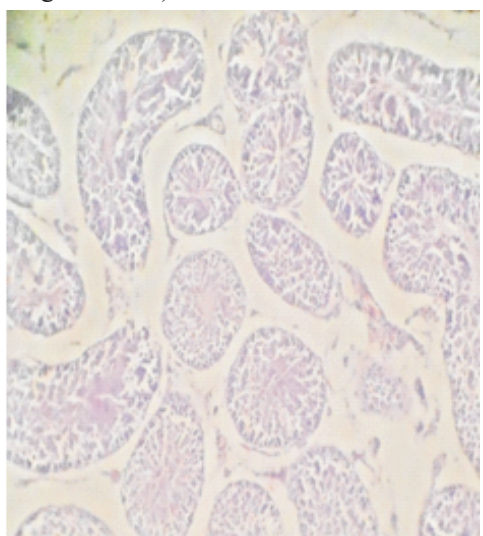

Plate J Photomicrograph of testicular tissue of Guinea pig supplemented with $0.1 \mathrm{mg}$ Se. Seminiferous tubules increased in diameter. (Haematoxylin and Eosine staining x400 magnification) 


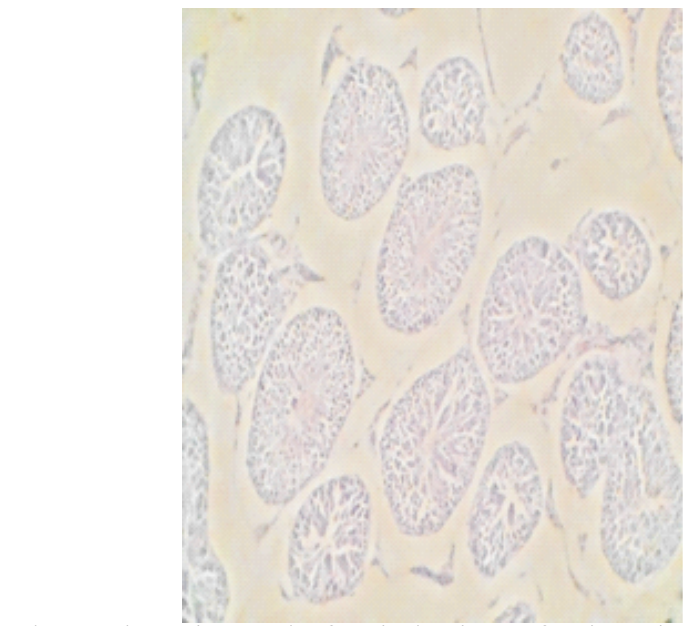

Plate K Photomicrograph of testicular tissue of Guinea pig supplemented with $0.2 \mathrm{mg}$ Se. Wider intertubuler spaces. (Haematoxylin and Eosine x400 magnification)

\section{Discussion \\ Effect of Vitamin $C, E$ and Selenium on testicular morphology of adult male guinea pigs}

The testicular dimension in guinea pigs fed vitamin $\mathrm{C}$, showed that there were no differences observed on the right and left testis width, right and left testicular length and testicular volume in guinea pigs though, differences were observed in the weight of the right testis and weight of the left testis, paired testes weight and testis density. The increase in testicular weight of guinea pigs supplement with vitamin $\mathrm{C}$ could be linked to vitamin $C$ effect on testis as Sapra et al. (1987) had earlier observed that vitamin $\mathrm{C}$ deficiency in guinea pigs caused a decrease in weight of the testis and accessory sex organs. This could be that dietary deficiency in guinea pigs markedly affected the androgen-sensitive parameters of the reproductive tissues-testis, epididymis, vas deferens, and accessory sex glands- and caused an "androgendeprived effect" in these target organs. This in turn altered their internal milieu and caused changes in their metal ion profile and the morphology, motility and density of spermatozoa in the cauda epididymis and

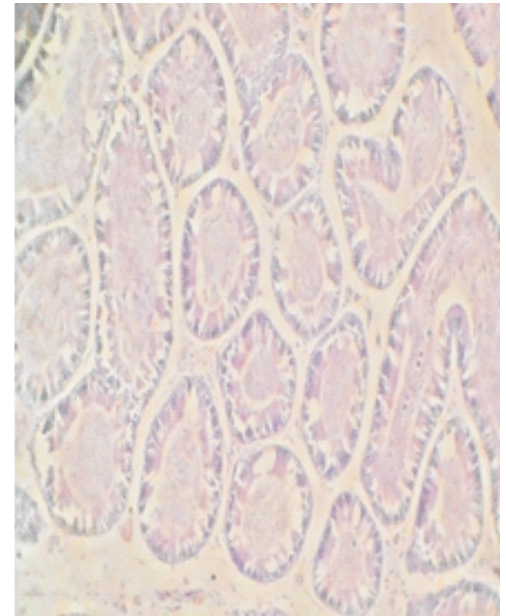

Plate L Photomicrograph of testicular tissue of Guinea pig supplemented with $0.3 \mathrm{mg}$ Se Dense and clustered seminiferous tubules. (Haematoxyline and Eosine staining x400 magnification).

vas deferences (Chinoy et al., 1986). From this study, guinea pigs administered 15 and $30 \mathrm{mg} / \mathrm{kg}$ vitamin $\mathrm{E}$ had better result for right, left and paired testes weight. High reduction in testis weight was observed in 0 $\mathrm{mg} / \mathrm{kg}$ vitamin E group. The seminiferous tubules occupy most of the testis volume, and also germinal cells are the most important components of testis tissue (O'Donnel et al., 2001), so the testis weight reduction may be correlated with the abnormal changes in the above-mentioned parameters. Therefore, administration of vitamin E could be compensatory agent of reduction of testicular weight. This supports Mehranjani et al; (2009) that administration of vitamin $\mathrm{E}$ with paranonypherol could compensate for the reduction of weight and volume of testis, volume of seminiferous tubules and its diameter and thickness of basement membrane, as well as number of type A spermatogonia, spermatocyte, spermatid and sertoli cells. Also a higher values of WRT, WLT, and PTW of guinea pigs supplemented with selenium occurs while RTV, RTL, LTL, RTW and LTW shows a similar values. The microphotograph plates A to L showing the testicular structure in the 
male guinea pig revealed there are considerable positive changes in seminiferous tubules density, size, morphological shapes and appearance. Similarly, the interstial tissues (intertubular space), basement membrane, leydig cells and darker stained spermatogonia however, are all varied considerably with increased dosage of both vitamin C, E and selenium. About $80 \%$ of the testicular microscopic structure obtained from this study was covered by seminiferous tubules which consists convulated structures such as spermatogenic cells and supporting sertoli cells and between the tubules are the interstial or leydigs cell which produce the male sex hormone. The density and enlargement of the tubular region clearly indicated the normal testicular exocrine and endocrine physiological activities. These are sperm production and secretion of the male hormone (androgen). Saddiqui et al. (2005) reported that reproductive performance of an animal has to be associated with functional morphology of the genital organs. Therefore, these studies on morphometric and histology appraisal of testicular parameters are valuable in reproductive management of guinea pigs. From this study the beneficial effects of selenium have been predominantly observed in the testes, where selenium directly affects the interstitial cells of the testes and seminiferous tubules.

\section{Conclusion}

The supplementation of adult male guinea pigs diets with vitamin $\mathrm{C}$, vitamin $\mathrm{E}$ and selenium improved testicular morphometric and had a considerable architectural histological changes in seminiferous tubules, interstitial cells size and shape.

\section{References}

Adebayo, A. O., Akinioye, A. K., Olukole, S. G., Oyeyemi, M. O., Taiwo, V.
O., Ihunwo, A. O. and Oke, B. O. 2005. Gross, histological and ultrastructural features of the bulbourethtal gland in the greater Cane rat ( Thryonomys swinderianus). Anatomia, Histologia and Embryologia, 44(1):59-65.

Chinoy, N. J., Mehta, R. R., Seethalakshmi, L., Sharma, J. D. and Chinoy, M. R. 1986. Effects ofvitamin C deficiency on physiology of male reproductive organs of guinea pigs. International Journal of Fertility, 31(3):232-239.

Eme, E. and Egbunike, G. N. 2010. Breed and seasonal variations in the testicularmorphometery, gonadal and extragonadal sperm reserves of the Barred Plmouth Rock and Nigerian Indigenous Breeds of the Domestic Fowl. Pakistan Journal of Biological Sciences, 13:120-125.

Franca, L. R. and Godinho, C. L. 2003 Testis morphometry, seminiferous epithelium, cycle

length, and daily sperm production in domestic cats (Felis catus). Biology of Reproduction, 68:15541561.

Hadden, J. W. 1987. Neuroendocrine modulation of the thymus-dependent immune system.

Annals of the New York Academy of Science, 496:39.

Institute for Agricultural Research. 2016. Meteorological unit, weather report, A h m a d u B 11 o University Zaria.

Jesse, B., Nick, H., Robert, P., Kevin, A. C., Keith, D. T., Penny, J., Alex, G., Nicholas, G and Mary, R. L. 2007. Sparing effects of selenium and ascorbic acids on vitamin $\mathrm{C}$ and $\mathrm{E}$ in guinea pig tissues. Nutrition Journal, 6:(7) doi:10.1186-2811-67. 
Lammers, P. J., Sarah, L. C., Gretechen, A. Z. and Mark, S. H. 2009. Reducing food insecurity indeveloping countries through meat production: the potential of the guinea pig (cavia porcellus). Renewable Agriculture and Food Systems, 24(2):155-162.

Lunstra, D. D., Wise, T. H. and Ford, J. J. 2003. Sertoli cells in the boar testis: changes during development and compasatory hypertrophy after hemi-castration of different ages. Biologyof Reproduction, 65:140-150.

Mehranjani, M. S., Noorafshan, A., Momeni, H. R., Abnosi, M. H., Mahmoodi, M., Anvari, M., Hoseini, S. M. 2009. Stereological study of the effects of vitamin $\mathrm{E}$ on testis structure in rats treated with para-nonylphenol. Asian Journal of Andrology, 11:508-516.

National Research Council 1995. Nutrient Requirement for laboratory Animals, fourth Revised Edition, 1995. Washingtonn DC: The National Academics press. Doi:10.17226/4758.

Neves, E. S., Chiarinn-Garcia, H. and Franca, L. A. 2002. Comparative testis morphometry and seminiferous epithelium cycle length in donkeys and mules. Biology of Reproduction, 67:247255.

O`Donnell, L., Robertson, K. M., Jones, M. E., Simpson, E. R 2001. Estrogen and spermatogenesis. Endrocrinology Research, 22:289318.

Okpe, G. C., Nwatu, U. and Anya, K. 2010. Morphometric study of the testes of the Nigerian local breed of chicken. Animal Research International, 7(2):1163-1168.

Ovimaps 2015. Map version 01.28.107.
Nokia ${ }^{\circledR}$ Corporation.

Padayatty, S. J., Katz, A., Wrang, Y., Eck, P. and Kwon, O. 2008. Vitamin C as an antioxidant evaluation of its role in human health Antioxidant Redox Signal, 9:775-806.

Pappas, A. C. and Zoidis, E. 2012. The role of selenium in chicken physiology: New insight in: chicken physiology, Diseases and farming practices, Kapur, I. and Mehra, A ( E d s.) Nova $\mathrm{S}$ c i e n c e Publishers inc; New York USA; ISBN-13:97816210279, Pp. 51-69.

SAS Institute, Inc. 2002. SAS User's guide: Statistics. Version 9. SAS Institute, Carry, NC 27513, USA.

Sapra, M., Sharma, P. and Kothari, L. K. 1987. Effect of vitamin C deficiency on testicularstructure i n $\mathrm{th} \mathrm{e}$ guinea pig. Journal of Postgraduate Medicine, 33:69-73.

Siddiqui, H. U. R., Ahmed, A. and Khan, M. Z. 2005. Biometrical studies of testes of ram. Journal of Agricultural Science, 1(1):78-79.

Stangland, B., Henson, D. E., Block, G. and Levine, M. 2008. Ascorbic acid: biological functions and relation to cancer. Journal of National Cancer Institution. 83(8):547-555.

Surai, P. F. and Sparks, N. H. C. 2006. Tissue-specific fatty acid and $\alpha$ tocopheral profile in male chickens depending on dietary tuna oil and vitamin E provision. Poultry Science, 79:1132-1143.

Wandzilak, T. R., D`Andre, S. D., Davis, P. A., Williams, E. A. and Oputri, D. 2013. Heparisprotective effect of vitamin C (Ascorbic acid). Pharmacology, 4(1) doi:10.4236/pp. 2013.41012.

Received: $30^{\text {th }}$ July, 2020 Accepted: $19^{\text {th }}$ November, 2020 